\title{
REDESCRIPTION OF THE ANT LEPTOTHORAX (S. STR.) SCAMNI RUZSKY, 1905
}

\author{
By J. Heinze ${ }^{1}$, A. SChulz ${ }^{2}$ AND A. G. RAdChENKo ${ }^{3}$
}

\begin{abstract}
Worker and queen caste of the ant Leptothorax (sensu stricto) scamni Ruzsky, 1905 are formally described and a neotype is designated. The species is distinguished from other Leptothorax (s. str.) by extraordinarily long, finger-shaped propodeal spines. $L$. scamni appears to be a rather rare, patchily distributed ant in alpine coniferous forests in the Caucasus (Russia and Armenia) and northern Turkey.
\end{abstract}

\section{INTRODUCTION}

The myrmicine ant genus Leptothorax comprises several hundred species of small to medium-sized ants, which live in inconspicuous, small colonies under stones, in rotting wood, or in hollow twigs. Most species occur in temperate or subtropical biomes and belong to the subgenera Myrafant M. R. Smith, Macromischa Roger, and others (e.g., Baroni-Urbani 1978, Bolton 1982). The subgenus Leptothorax (s. str.) (= Mychothorax Ruzsky), on the other hand, is comparatively poor in species, which all are confined to boreal and alpine habitats. In addition to three or four social parasites, Leptothorax (s. str) consists of about half a dozen of nearctic taxa, most of which are as yet not reliably defined (Creighton 1951, Brown 1955, Heinze 1989), and three well-studied palaearctic species: Leptothorax acervorum (Fabricius, 1793), L. muscorum (Nylander, 1846), and L. gredleri Mayr, 1855. A fourth palaearctic taxon, $L$. scamni Ruzsky, 1905 was originally described as a Caucasian variety of $L$. muscorum and later transformed into a good species without additional information by Arnol'di (1977). It appears that neither Ruzsky (1905) nor Arnol'di (1977) did designate

\footnotetext{
${ }^{1}$ Theodor-Boveri-Institut, LS Verhaltensphysiologie und Soziobiologie, Am Hubland, D 97074 Würzburg, F. R. Germany

2 Feldstraße 66, D 51381 Leverkusen

${ }^{3}$ Inst. of Zoology, 15 ul. Bogdan Khmel'nitskogo, Kiev 252030, Ukraina

Manuscript received 19 July 1993.
} 
type material. An additional taxon, Leptothorax oceanicum Kuznetzov-Ugamskij, 1928, was described as a subspecies of $L$. muscorum from eastern Siberia (southern Primorsky and Khabarovsky districts; Kuznetzov-Ugamskij 1928, 1929; Kupianskaya 1990) and is considered a good species after examination by one of us (A. G. R.).

We recently collected specimens of an apparently rare Leptothorax (s. str.) in Turkey (J. H., A. S.) and the Caucasus (A. G. R.), which exactly fit Ruzsky's description of L. scamni. As this species has been widely ignored by myrmecologists studying Leptothorax (s. str.) we here give a tentative translation of Ruzsky's Russian original description, a complete description of Leptothorax scamni, and summarize the scanty information we have on its occurrence and biology.

\section{Original description (Ruzsky 1905)}

\section{L. muscorum var. scamni nov. var.}

Worker: Propodeal spines large, long, slightly curved, fingershaped. At least 3/4 as long as length of dorsal surface of propodeum (in typical $L$. muscorum only $1 / 2$ ). The spines are rather broad at their bases, but immediately become narrow and remain narrow, rounded, and evenly thin all the way to the tip (for $2 / 3$ or $3 / 4$ of their length). The tip is rounded and blunt (the spines of typical $L$. muscorum narrow steadily and end in an acute tip). The sculpture of the body is finer and denser than in the type; petiole and a large part of the thorax with predominantly fine puncturing. Posterior side of the petiolar node markedly convex. Color and size as in the type. Individual workers were collected from a bench on a mountain path in the district of Abastumani (July 14, 1899 [Georgia]). In the district of Vladikavkaz [from appr. 1930 to 1990 Ordzhonikidze, North Ossetia] a small colony was found in the bark of a hollow beech (July 3, 1899).

\section{Note by Arnol'di (1977)}

\section{Leptothorax (Mychothorax) scamni}

L. muscorum v. scamni Ruzsky, 1905: 620.

A large compact ant distinguished by strongly developed rodlike spines; a distinct species that is widely distributed in the upper forest and subalpine zone of the Caucasus. 


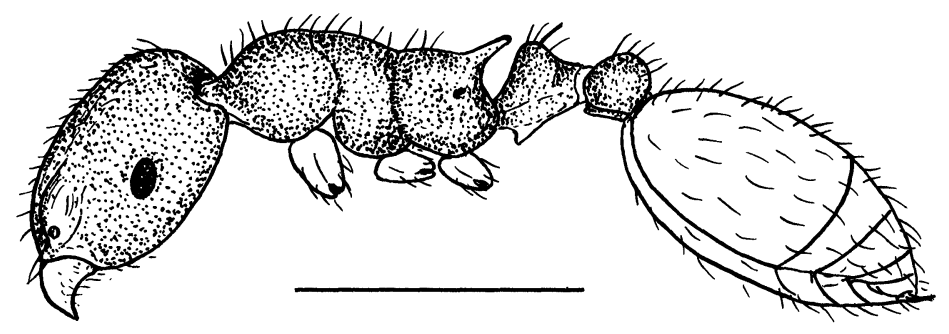

Fig. 1. Habitus of neotype worker of Leptothorax (s. str.) scamni from Shuntuck, Maykop distr., Russia (scale: bar $=1 \mathrm{~mm}$ ) (drawing by A. G. R.)

Leptothorax scamni Ruzsky, 1905

Description of the worker

Neotype: Worker from Shuntuck, Maykop distr. (northern Caucasus: Adygey Aut. Oblast, Russia), Nr. A 6008 (leg. K. Arnol'di, without date), deposited at the Zoological Museum of Moscow State University, Moscow, Russia (Fig. 1).

Total length appr. $3.5 \mathrm{~mm}$, head length (excluding mandibles) 0.81 , head width (behind eyes) 0.71 , scape length 0.56 , maximum eye diameter 0.15 , thorax length (diagonal) 1.06 , thorax width 0.46 , length of petiole in lateral view 0.38 , height of petiole at node in lateral view 0.28 , maximum width of petiole 0.19 , length of postpetiole in lateral view 0.24 , height of postpetiole 0.25 , maximum width of postpetiole 0.27 , length of hind femur 0.63 , length of hind tibia 0.51. Antennae 11-segmented with a 3-jointed apical club. Clypeus deeply notched. Promesonotal suture very distinct, but appearing only slightly impressed in side view. Propodeal spines long, rod-shaped, distal part slightly curved with a blunt tip. Propodeal spine index (Buschinger 1966) appr. 2.0. Head, thorax, petiole, and postpetiole with fine punctulation, head with shallow rugae in addition. Head and gaster dark brown, thorax, petiole, postpetiole, scapes and legs yellowish-brown.

Specimens collected at Gürgentepe Geçidi (Ordu prov., northern Turkey) and material from various areas in the Caucasus closely resemble the neotype. Workers from Artvin (northeastern Turkey) 
differ in that their propodeal spines are more acute, the ventral petiolar process is more pronounced, and the promesonotal suture is less strongly impressed. Size measurements of material from the Caucasus vary as follows: head length $0.80-0.90 \mathrm{~mm}$, head width $0.67-0.74$, scape length $0.56-0.60$, thorax length $1.06-1.19$.

\section{Description of the queen}

Dealate queen from Yeniçaga Gölü, Bolu prov., northern Turkey

Total length appr. $4.1 \mathrm{~mm}$, head length 0.86 , head width 0.74 , scape length 0.58 , maximum eye diameter 0.21 , thorax length 1.32 , maximal width of thorax 0.62 , length of petiole 0.38 , height of petiole 0.44 , width of petiole 0.20 , length of postpetiole 0.28 , height of postpetiole 0.28 , width of postpetiole 0.34 , length of hind femur 0.76 , length of hind tibia 0.58 .

The habitus of the neotype queen (Fig. 2) is similar to that of queens of other Leptothorax (s. str.). Antennae 11-segmented with a 3-jointed apical club. Mandibles with six teeth. Three ocelli present. Anterior border of clypeus with a distinct notch as in $L$. gredleri (e.g., Buschinger 1966) or L. retractus (Francoeur 1986). Propodeal spines very long, rod-like, with a blunt tip; propodeal spine index appr. 1.9. In lateral view, petiolar node flat, grading smoothly into the weakly convex posterior surface, but separated from the concave anterior surface by a right angle. Postpetiole in dorsal view slightly trapezoidal, in lateral view with a small, sharp ventral tooth. Head, pronotum and scutum rugulose with interrugal spaces punctulate, rest of thorax, petiole and postpetiole finely

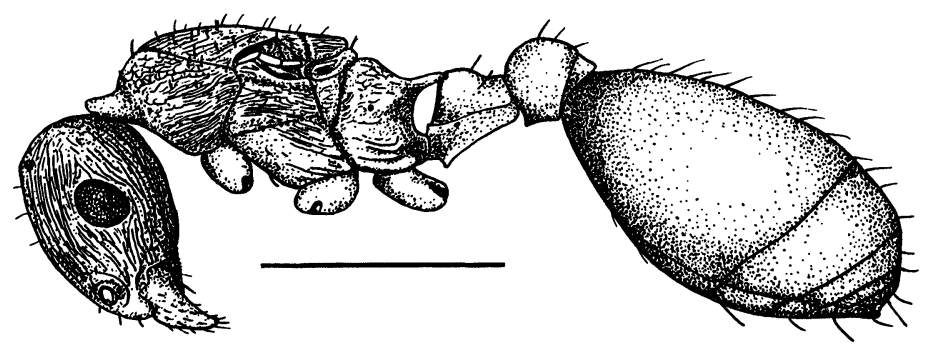

Fig. 2. Habitus of a queen of Leptothorax scamni from Ilgazdagi Geçidi, Çankiri prov., Turkey (scale: bar $=1 \mathrm{~mm}$ ) (drawing by J. H.). 
punctulate, gaster smooth and shining. Body covered with long, erect or suberect hairs, legs and scapes with moderately abundant appressed hairs. Coloration a light brown, dorsal parts of thorax and gaster darker brown.

\section{Disposition of types}

The neotype worker is deposited in the Zoological Museum of Moscow State University, Moscow, Russia (Nr. A 6008). In this collection, several additional specimens of $L$. scamni were identified. A queen from Yeniçaga Gölü (Bolu prov., northern Turkey) and a worker from Gürgentepe Geçidi (Ordu prov., northern Turkey) are deposited in the Museum of Comparative Zoology, Harvard University, Cambridge, Mass. Two workers are in the collection of the Musée d'histoire naturelle in Geneva, Switzerland.

\section{Diagnosis}

As Ruzsky (1905) clearly mentioned in the original description, the most distinctive characters of $L$. scamni are the extraordinarily long, finger-shaped propodeal spines in both female castes. Only in L. acervorum and in an as yet undescribed nearctic Leptothorax sp. A are the spines as long. However, in those species the spines are acutely tapering, not rod-shaped. In addition, $L$. scamni differs from holarctic $L$. acervorum in the lack of erect, stiff hairs on scapes and legs and by its notched clypeus. From nearctic Leptothorax sp. A, L. scamni differs in the shapes of the petiole in lateral view and of the postpetiole in dorsal view. In Leptothorax sp. $\mathrm{A}$, the ventral petiolar process is very pronounced and drop-shaped and the postpetiole as seen from above is distinctly trapezoidal (for a more detailed diagnosis of the latter species see Heinze and Buschinger 1987, Heinze and Alloway 1991).

\section{Biology}

According to Arnol'di (1971), L. scamni is a common ant throughout alpine coniferous forests in the Caucasus, and indeed, in the Zoological Museum of Moscow State University, several specimens from various parts of the Caucasus are deposited (Shuntuck, Majkop distr.; Khamyshky, Kuban distr.; Karaklis, Armenia; Caucasian Natural Reservation). Nevertheless, an examination of specimens of Leptothorax (s. str.) collected in the Caucasus by B. Seifert, Naturkundliches Museum Görlitz, F. R. G., 
revealed numerous $L$. acervorum and $L$. muscorum, but not a single $L$. scamni, and only few specimens of $L$. scamni are present in the material collected in the Caucasus by A. G. R. One worker, e.g., was collected in the district of Shamshadinsk, Armenia, at an elevation of $2000 \mathrm{~m}$ (Aug. 13, 1986). From Turkey, at present only five workers and two queens are known, all collected in mountainous areas in the north of the country, less than one hundred kilometers from the Black Sea coast. The two dealate L. scamni queens, probably colony foundresses collected shortly after the mating flight, were found without workers and brood, one under bark in a poplar plantation at the Yeniçaga Gölü (Bolu prov., 1000 m elev., July 8, 1986, J. H.) and the other in a south-exposed, rotting tree stump in an alpine fir (Abies nordmanniana) forest at Ilgaz Dagi Geçidi (Çankiri prov., $1800 \mathrm{~m}$ elev., July 8, 1986, J. H.). Three workers were collected in an oak forest near Gürgentepe Geçidi, (Ordu prov., appr. 1200 m elev., July 5, 1989, A. S.), the remaining two workers are from the collection of the Musée d'histoire naturelle in Geneva, Switzerland and bear labels with the location designations "Artvin, SW Artvin, 1900 m" (9.6.1986; Besuchet-Löbl, Burckhardt) and "Artvin, Pirnalli, massif du Karkal Dagi, 1600 m" (June 11, 1986, Besuchet-Löbl, Burckhardt) (Artvin prov., northeastern Turkey). A thorough search for complete colonies in 1991 at the very site at Ilgaz Dagi Geçidi, where a dealate queen had been found five years before, was unsuccessful, though some thirty colonies of $L$. acervorum and $L$. muscorum were collected. In several museum and private collections, specimens of $L$. acervorum and $L$. muscorum form Turkey are present, but none of $L$. scamni. We therefore suggest that the latter species rarely occurs in dense populations, but may be a patchily distributed habitat specialist, such as L. gredleri in Central Europe.

\section{ACKNOWLEDGEMENTS}

We thank Dr. C. Bésuchet (Musée d'histoire naturelle, Geneva, Switzerland), Dr. Brancucci (Naturhistorisches Museum, Basle, Switzerland), Dr. C. A. Collingwood (City Museum, Leeds, U. K.), Dr. M. Fischer (Naturhistorisches Museum, Vienna, Austria), Dr. B. Poldi (Mantova, Italy), and Dr. B. Seifert (Staatl. Museum für Naturkunde Göirlitz, F. R. Germany), for providing material from 
their collections of ants from the Caucasus or Turkey. S. P. Cover, MCZ, Cambridge, Mass. made helpful comments on the manuscript.

\section{REFERENCES}

ARNOL'DI, K. V.

1977. New and little known species of the genus Leptothorax (Mayr) (Hymenoptera, Formicidae) in the European regions of the USSR and the Caucasus. Entomol. Rev. 56: 148-153.

BARONI-URBANI, C.

1978. Materiali per una revisione dei Leptothorax neotropicali appartenenti al sottogenere Macromischa Roger n. comb. (Hymenoptera: Formicidae). Entomol. Basil. 3: 395-618.

Bolton, B.

1982. Afrotropical species of the myrmicine ant genera Cardiocondyla, Leptothorax, Melissotarsus, Messor and Cataulacus (Formicidae). Bull. Brit. Mus. (Nat. Hist.), Ser. Entomol. 45: 307-370.

Brown, W. L.

1955. The ant Leptothorax muscorum in North America. Ent. News 66: 43-50.

BUSCHINGER, A.

1966. Leptothorax (Mychothorax) muscorum Nylander und Leptothorax (M.) gredleri Mayr zwei gute Arten. Ins. Soc. 13: 165-172.

Creighton, W. S.

1950. The ants of North America. Bull. Mus. Comp. Zool. [Mass]. 104, 585 $\mathrm{pp}$.

Francoeur, A.

1986. Deux nouvelles fourmis néarctiques: Leptothorax retractus and Leptothorax sphagnicolus (Formicidae, Hymenoptera). Can. Ent. 118: 1151-1164.

HEINZE, J.

1989. A biochemical approach toward the systematics of the Leptothorax "muscorum" group in North America (Hymenoptera: Formicidae). Biochem. Syst. Ecol. 17: 595-601.

HEINZE, J. AND BUSCHINGER, A.

1987. Queen polymorphism in a non-parasitic Leptothorax species (Hymenoptera, Formicidae). Ins. Soc. 34: 28-43.

Heinze, J. AND Alloway, T. M.

1991. Leptothorax paraxenus, n. sp., a workerless social parasite from North America (Hymenoptera: Formicidae). Psyche 98: 195-206.

KuPIANSKAYA, A. N.

1990. Ants of the Far East of the USSR. Vladivostok, 258 pp. (in Russian)

KuZNETZOV-UgAmSKIJ, N. N.

1928. Ants of the South Ussuri-District. Zap. Vladivostok. otd. russk. geogr. ob-va. 1, 1-47. (in Russian)

1929. Die Ameisen des Süd-Ussuri-Gebietes. Zool. Anz. 83: 16-34.

RUZSKY, M.

1905. Formicariae Imperici Rossici. Trudi obsces. Est. Imp. Kasan Univ. 37, 1-800. (in Russian) 

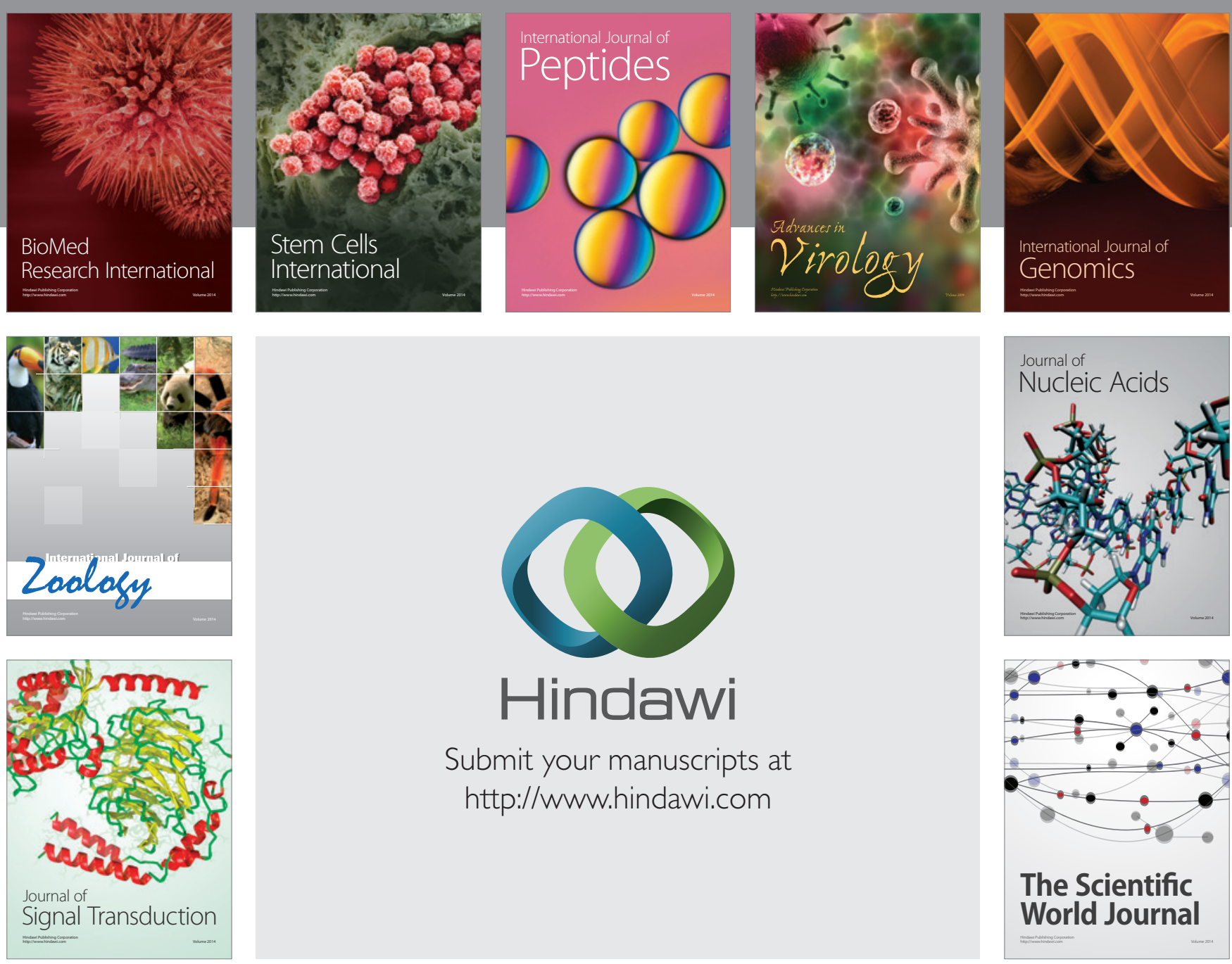

Submit your manuscripts at

http://www.hindawi.com
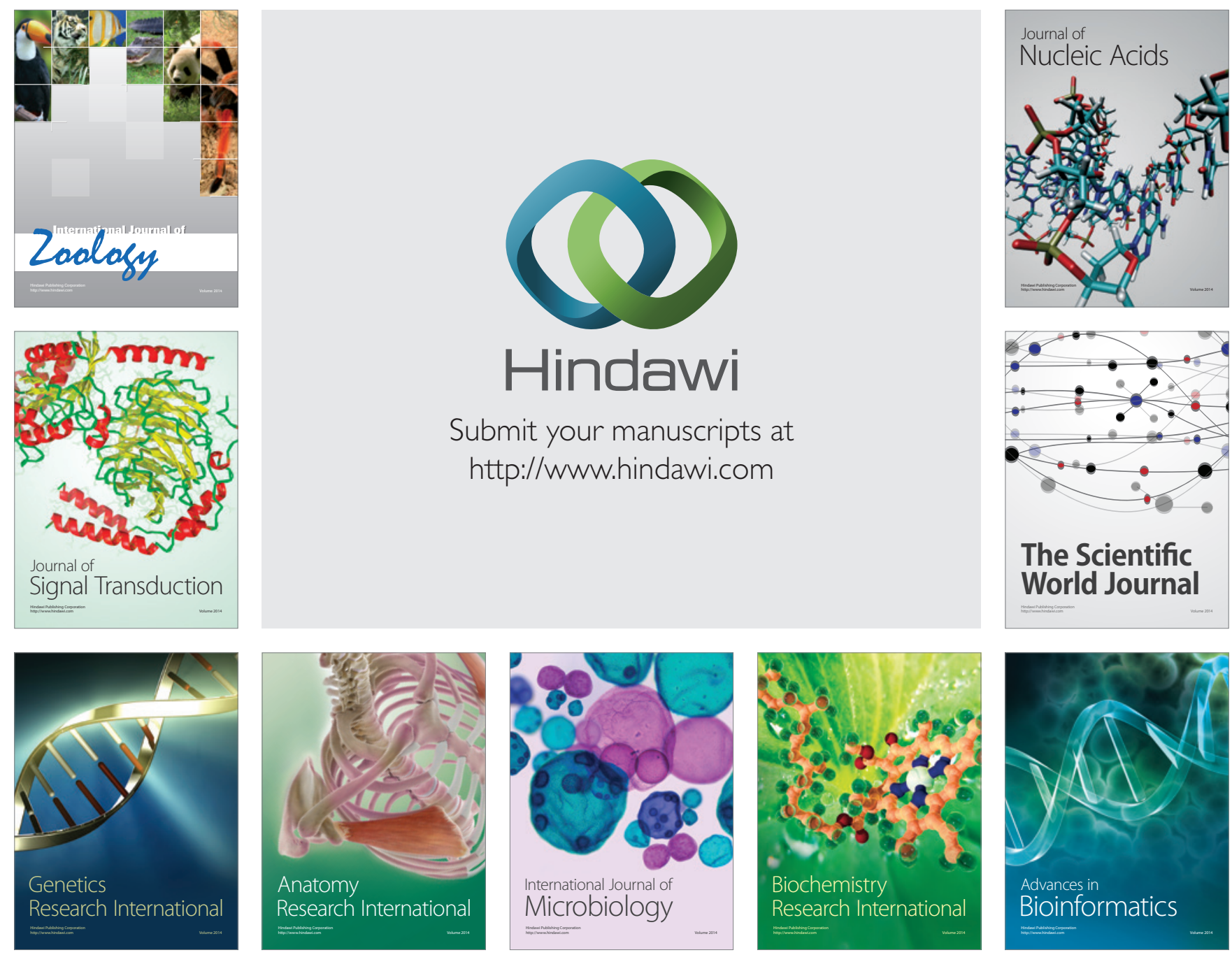

The Scientific World Journal
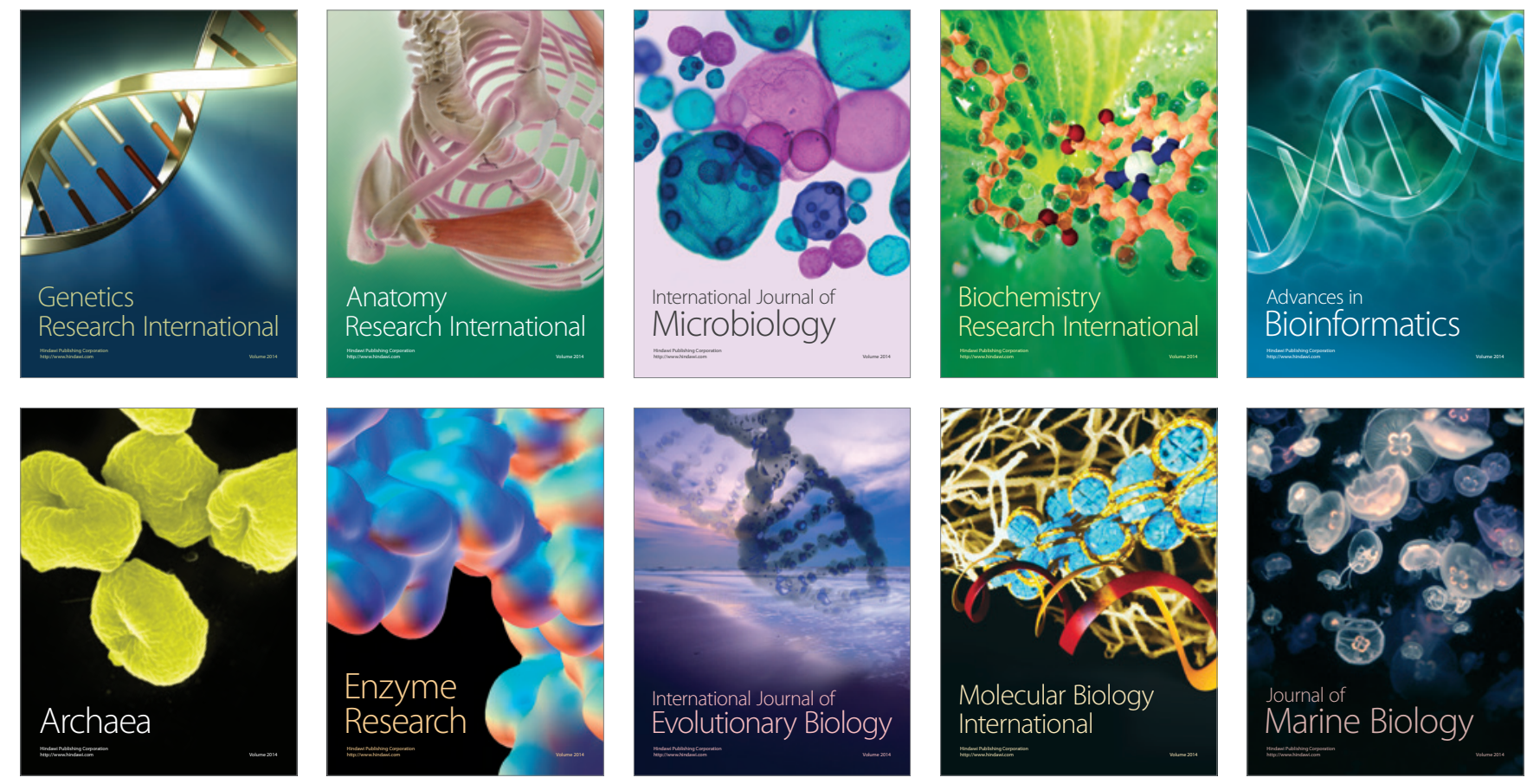